\title{
A Rare Case of Spontaneous Intrauterine Skull Fracture
}

\section{Caso Raro de Fratura Espontânea Intrauterina do Crânio}

\begin{abstract}
Mariana DÓRIA ${ }^{*}, 1$, Catarina VIVEIROS*,2, Lia Rodrigues e RODRIGUES ${ }^{3}$, Fátima SOARES 1
Acta Med Port 2020 May;33(5):344-346 - https://doi.org/10.20344/amp.11565

\section{ABSTRACT}

Skull fractures are rare in newborns and normally caused by maternal abdominal trauma or complicated deliveries. However, in rare cases, these fractures are found in neonates born after an uneventful pregnancy and delivery. We report a case of a primigravida who underwent cesarean delivery due to failure of descent and malpositioning of the fetal head. After birth, a right temporoparietal fracture and congenital muscular torticollis were diagnosed. The newborn's blood tests showed hypocalcemia and relative hypoparathyroidism. Both mother and newborn presented low vitamin D levels. Serial imaging control showed gradual resolution of the lesions, with the newborn being discharged at the $10^{\text {th }}$ day of life with vitamin $D$ supplementation. This is an interesting case because the combination of three conditions - maternal and fetal hypovitaminosis $\mathrm{D}$, congenital torticollis and malposition of the cephalic pole during labor - may have synergistically contributed to a spontaneous intrauterine skull fracture.
\end{abstract}

Keywords: Hypocalcemia; Infant, Newborn; Skull Fractures; Torticollis/congenital; Vitamin D Deficiency

\section{RESUMO}

As fraturas do crânio são raras em recém-nascidos, sendo mais comummente causadas por trauma abdominal ou como complicação do parto. Contudo, em casos mais raros, estas fraturas são encontradas isoladamente, sem associação a intercorrências da gravidez ou do parto. Apresentamos o caso de uma primigesta submetida a cesariana por ausência de descida da apresentação e mau posicionamento da mesma no canal de parto. Após o nascimento, foi diagnosticada fratura temporoparietal direita e torcicolo congénito. Analiticamente, o recém-nascido apresentava hipocalcemia e hipoparatiroidismo relativo. A díade mãe - recém-nascido apresentaram hipovitaminose D. Estudos imagiológicos seriados demonstraram resolução gradual das lesões, possibilitando a alta do recém-nascido ao $10^{\circ}$ dia de vida com suplementação de vitamina D. Este caso é interessante porque se conjugam três condições - hipovitaminose D materna e fetal, torcicolo congénito e má orientação do polo cefálico - que, conjuntamente, podem ter contribuído para a ocorrência de fratura craniana intrauterina espontânea.

Palavras-chave: Deficiência de Vitamina D; Fraturas Cranianas; Hipocalcemia; Recém-Nascido; Torcicolo/congénito

\section{INTRODUCTION}

Skull fractures found in newborns can be linear, usually affecting the parietal bones, or depressed, the so called 'ping-pong fractures'. Linear fractures, unlike depressed fractures, are not generally accompanied by underlying brain lesions and do not require specific treatment. ${ }^{1}$

Cerebral computed tomography (CT) scan, with pediatric low-dose radiation protocol, is the gold standard for the diagnosis. $^{2}$

Most common causes are maternal abdominal trauma during pregnancy and head injuries caused by instruments or obstetrical maneuvers in complicated deliveries. ${ }^{3}$ However, in rare cases, these fractures are found in neonates born after an uneventful pregnancy and delivery and are, in these instances, called 'spontaneous'. ${ }^{4}$

It is likely that these 'spontaneous' fractures may result from continuous intrauterine mechanical forces upon the soft fetal skull caused by bony structures. ${ }^{5}$

Additionally, some vitamin deficits may result in a higher probability of fracture. Vitamin D plays a central role in calcium and phosphate homeostasis and bone metabolism. In the presence of vitamin $D$ deficiency, the intestine is not capable of absorbing calcium and phosphate adequately, leading to secondary hyperparathyroidism. ${ }^{6}$

Severe deficits of vitamin $D$ during pregnancy have been associated with compromise of skeletal fetal homeostasis, congenital rickets and fractures in the newborn, as well as neonatal hypocalcemic seizures, since the newborn levels of vitamin $\mathrm{D}$ are largely dependent on maternal vitamin $\mathrm{D}$ status. ${ }^{6}$ One of the signs of maternal vitamin $D$ deficiency is craniotabes, a softening of skull bones, which makes the bone more prone to fractures. ${ }^{7}$ Moreover, maternal vitamin D insufficiency correlates with higher risk of pre-eclampsia, gestational diabetes, preterm birth or low birth weight. ${ }^{6}$

\section{CASE REPORT}

We report a case of a 31-year-old primigravida with no significant medical history. She took a multivitamins including $5 \mu \mathrm{g}$ of vitamin $\mathrm{D}$ during pregnancy. The pregnancy was uneventful until 33 weeks, when she presented with threatened preterm labor and did a course of antenatal corticosteroids for fetal maturation. No trauma was reported during pregnancy.

She presented to our emergency department at 38 weeks and four days after premature rupture of membranes

\footnotetext{
* Co-primeiros autores

1. Serviço de Ginecologia/Obstetrícia. Unidade Local de Saúde de Matosinhos. Hospital Pedro Hispano. Matosinhos. Portugal.

2. Serviço de Pediatria. Unidade Local de Saúde de Matosinhos. Hospital Pedro Hispano. Matosinhos. Portugal.

3. Serviço de Neonatologia. Unidade Local de Saúde de Matosinhos. Hospital Pedro Hispano. Matosinhos. Portugal.

$\triangle$ Autor correspondente: Mariana Dória. mariana.doria@ulsm.min-saude.pt

Recebido: 14 de novembro de 2018 - Aceite: 06 de fevereiro de 2019 | Copyright $\odot$ Ordem dos Médicos 2020
} 
in labor. At admission, cervix was $2 \mathrm{~cm}$ dilated and $100 \%$ effaced with cephalic presentation. Cardiotocography was reassuring.

A cesarean was performed due to failure of descent and fetal malpresentation (no engagement and head hyperextension). No forceps or vacuum extractor were used.

Newborn Apgar score was 9/10 at one and five minutes, respectively. Weight was appropriate for gestational age. Physical examination showed right hemicranium tumefaction of soft consistency, with crackling in the right temporoparietal transition and left congenital muscular torticollis (CMT). Neurologic examination was adequate to the gestational age. Skull x-ray suggested a fracture in the right temporoparietal region (Fig. 1).

CT scan confirmed the diagnosis showing a solution of continuity in the right parietal convexity, with misalignment of bony tops, compatible with a linear fracture and also three focus of haemorrhage: a right temporoparietal haemorrhagic contusion measuring $9.3 \times 6.7 \times 4.3 \mathrm{~mm}$, a smaller one laterally and linear traces of adjacent sulcal subarachnoid haemorrhage (Fig. 2).

Both mother and newborn presented hypocalcemia (8.6 $\mathrm{mg} / \mathrm{dL}$ and $6.9 \mathrm{mg} / \mathrm{dL}$ ) and vitamin D insufficiency $(16 \mathrm{ng} / \mathrm{mL}$ and $11 \mathrm{ng} / \mathrm{mL}$ ), respectively. Parathormone (PTH) levels in the newborn were within normal range, although inappropriately low $(45.8 \mathrm{pg} / \mathrm{mL})$ in the presence of hypocalcemia. The newborn also presented with hyperphosfatemia (10.4 $\mathrm{mg} / \mathrm{dL}$ ) and hypomagnesemia (1.45 mg/dL) (Table 1).

Serial brain CT scans (D3 and D8) were performed, with evidence of partial reabsorption of intra-axial haemorrhagic lesion and resolution of subarachnoid haemorrhage. The skeleton x-ray showed no evidence of additional fractures. The neurological examination was always normal.

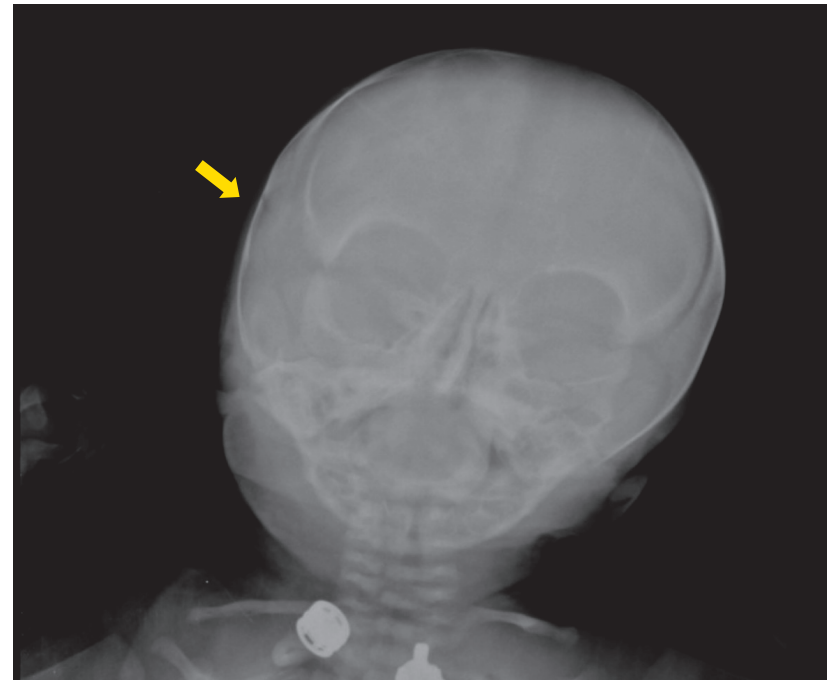

Figure 1 - Skull x-ray: right temporoparietal fracture

The newborn was discharged at D10 with vitamin D and calcium supplementation and maintained multidisciplinary follow-up, with normal physical and psychomotor development. No sequels were identified.

\section{DISCUSSION}

The prevalence of spontaneous intrauterine skull fractures varies from 1 in 4000 to 1 in 10000 deliveries. ${ }^{8}$ Establishing etiology can be challenging, especially when there is no evidence of abdominal trauma, no use of instruments or after a cesarean section delivery.

There are few similar cases in the literature, with the majority of studies describing depressed skull fractures. To our knowledge, this is the first case report of a linear fracture in a non-traumatic delivery of a newborn with docu-

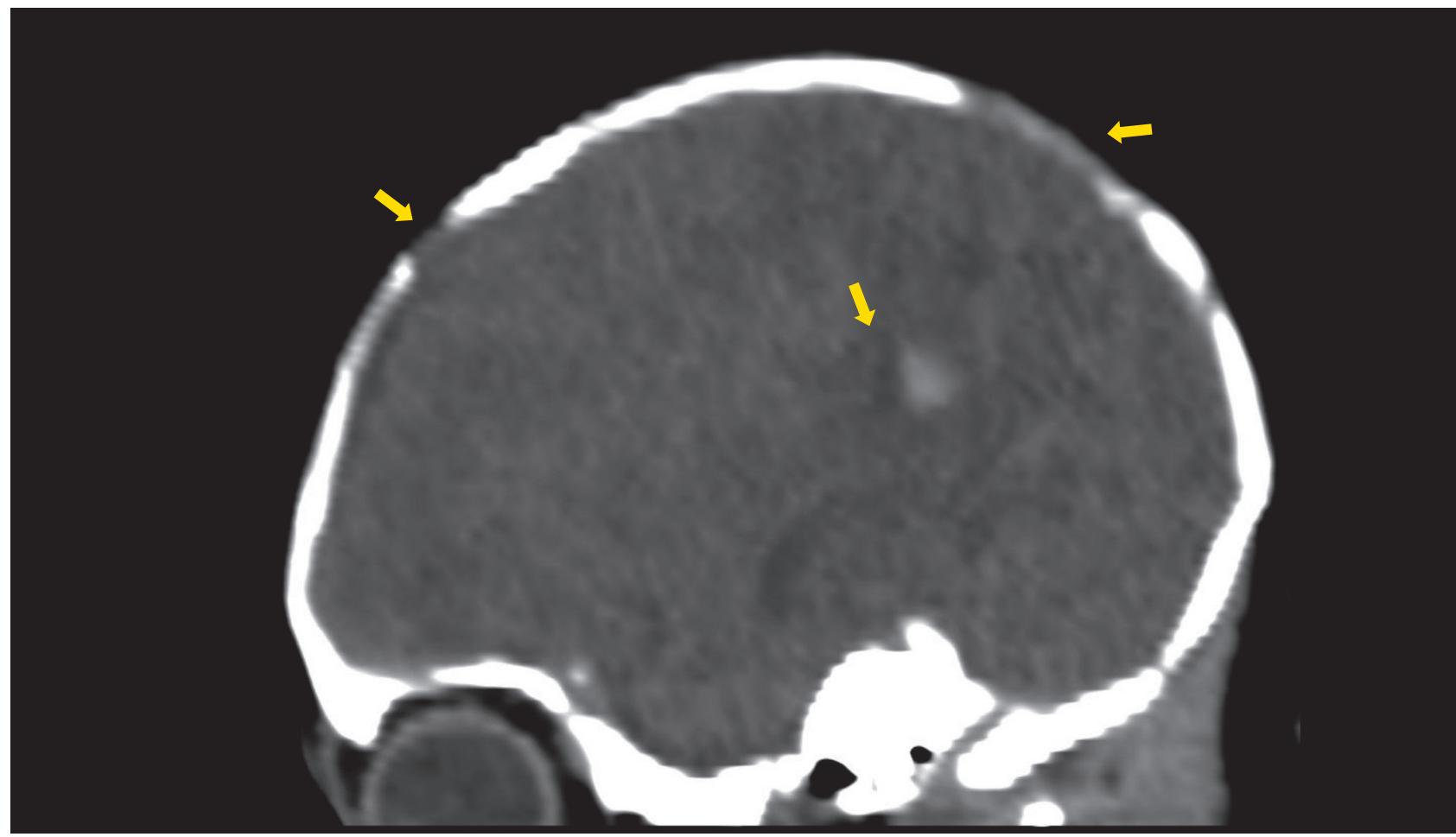

Figure 2 - Brain computed tomography scan in D2. Visible three focus of hemorrhage. 
Table 1 - Blood laboratory findings of the newborn and his mother. Reference ranges are presented inside parentheses.

\begin{tabular}{lcc}
\hline Parameter & Newborn & Mother \\
\hline Calcium $(\mathrm{mg} / \mathrm{dL})$ & $6.9(7.6-10.4)$ & $8.6(8.9-10.0)$ \\
Vitamin D $(\mathrm{pg} / \mathrm{mL})$ & $11(16-65)$ & $16(30-100)$ \\
PTH $(\mathrm{pg} / \mathrm{mL})$ & $45.8(15-65)$ & --- \\
Phosphorus $(\mathrm{mg} / \mathrm{dL})$ & $10.4(4.5-9.0)$ & --- \\
Magnesium $(\mathrm{mg} / \mathrm{dL})$ & $1.45(1.6-2.3)$ & ---- \\
\hline
\end{tabular}

PTH: parathyroid hormone

Adapted from Tschudy M. The Harriet lane Handbook. $19^{\text {th }}$ ed. Amsterdam: Elsevier Mosby; 2011.

mented hypovitaminosis $\mathrm{D}$. There are no described cases of fractures attributed to vitamin D deficiency, although it has been cited as a cause of congenital rickets and it has been associated with suboptimal fetal growth and reduced fetal skull mineralization. ${ }^{9}$

Vitamin D deficiency screening is based on the measurement of serum concentrations of 25-hydroxivitamin D $[25(\mathrm{OH}) \mathrm{D}]{ }^{6}$ According to the 2016 Global Consensus recommendations, levels comprised between 20-100 ng/ $\mathrm{mL}$ are considered normal, with insufficiency in the range $12-20 \mathrm{ng} / \mathrm{mL}$ and deficiency when values are less than 12 $\mathrm{ng} / \mathrm{mL} .{ }^{10}$ There is no consensus on an optimal vitamin D level during pregnancy status and it remains unclear whether vitamin D supplementation should be routinely recommended in pregnancy or if it should be reserved for highrisk groups. ${ }^{11}$

Vitamin $\mathrm{D}$ deficiency in neonates secondary to maternal deficiency may lead to hypocalcemia. PTH should increase in response to low serum calcium concentrations, but that was not found in our case, with PTH levels abnormally low for the level of hypocalcemia. This suggests a relative hypoparathyroidism, which may also have contributed to newborn hypocalcemia. ${ }^{12}$

Birth trauma has been suggested as the main etiological factor for congenital muscular torticollis (CMT). ${ }^{13}$ However,
CMT has also been described in cases where no trauma was reported. In our case, congenital muscular torticollis may have been caused by an abnormal intrauterine position during the third trimester which resulted in sternocleidomastoid muscle injury and deformity, as proposed by Stellwagen et al. ${ }^{14}$

The fetal malpresentation, probably due to CMT, may have predisposed the fetus skull to collision with maternal body structures, especially during uterine contractions. The vitamin $\mathrm{D}$ deficit and hypocalcemia may have contributed to softening of the fetus skull, predisposing it to fracture.

This is a challenging case in which the combination of three conditions - maternal and fetal hypovitaminosis D, congenital torticollis and fetal malpresentation - may have synergistically contributed to a spontaneous intrauterine skull fracture.

\section{PROTECTION OF HUMANS AND ANIMALS}

The authors declare that the procedures were followed according to the regulations established by the Clinical Research and Ethics Committee and to the Helsinki Declaration of the World Medical Association.

\section{DATA CONFIDENTIALITY}

The authors declare having followed the protocols in use at their working center regarding patients' data publication.

\section{PATIENT CONSENT}

Obtained.

\section{CONFLITS OF INTEREST}

The authors declare that there are no conflicts of interest.

\section{FUNDING SOURCES}

No subsidies or grants contributed to this work.

\section{REFERENCES}

1. Doumouchtsis SK, Arulkumaran S. Head injuries after instrumental vaginal deliveries. Curr Opin Obstet Gynecol. 2016;18:129-34.

2. Mutch C, Talboot J, Gean A. Imaging evaluation of acute traumatic brain injury. Neurosurg Clin N Am. 2016;27:409-39.

3. Zalatimo $O$, Ranasinghe $M$, Dias M, Lantosca M. Treatment of depressed skull fractures in neonates using percutaneous microscrew elevation. J Neurosurg Pediatr. 2012;9:676-9.

4. Mastrapa TL, Fernandez LA, Alvarez MD, Storrs BB, Flores-Urueta A. Depressed skull fracture in Ping Pong: elevation with Medeva extractor. Childs Nerv Syst. 2007;23:787-90.

5. Guha-Ray DK. Intrauterine spontaneous depression of fetal skull: a case report and review of literature. J Reprod Med. 1976;16:321-4.

6. American College of Obstetricians and Gynecologists. Vitamin D: screening and supplementation during pregnancy. Obstet Gynecol 2011 (reaffirmed 2017);118:197-8.

7. Yorifuji J, Yorifuji T, Tachibana K, Nagai S, Kawai M, Momoi T, et al. Craniotabes in normal newborns: the earliest sign of subclinical vitamin D deficiency. J Clin Endocrinol Metab. 2008;93:1784-88.

8. Aliabadi H, Miller J, Radnakrishnan S, Mehta Al, Thomas K, Selznick L, et al. Spontaneous intrauterine "ping-pong" fracture: review and case illustration. Neuropediactics. 2009;40:73-5.

9. Morgan JA, Marcus PS. Prenatal diagnosis and management of intrauterine fracture. Obstet Gynecol Surv. 2010;65:249-59.

10. Munns CF, Shaw N, Kiely M, Specker BL, Thacher TD, Ozono K, et al. Global consensus recommendations on prevention and management of nutritional rickets. J Clin Endocrinol Metab. 2016;101:394-415.

11. Steer $P J$. Is vitamin $D$ supplementation in pregnancy advisable? Lancet. 2013;381:2143-5.

12. Ashraf A, Mick G, Atchison J, Petrey B, Abdullatif H, McCormick K. Prevalence of hypovitaminose $D$ in early infantile hypocalcemia. J Pediatr Endocrinol Metab. 2006;19:1025-32.

13. Hardgrib N, Rahbek O, Moller-Madsen B, Maimburg R. Do obstetric risk factors truly influence the etiopathogenesis of congenital muscular torticollis? J Orthop Traumatol. 2017;18:359-64.

14. Stellwagen L, Hubbard E, Chambers C, Jones KL. Torticollis, facial asymmetry and plagiocephaly in normal newborns. Arch Dis Child. 2008;93:827-31. 